\author{
Alona Melnyk, \\ Doctor of Economics, Professor, \\ Kyiv National University of Technologies and Design, \\ 2, Nemyrovycha-Danchenka Street, Kyiv, 01011, Ukraine, \\ ORCID: 0000-0002-4051-3033 \\ ResearccherID: A-4683-2019 \\ Zorina Shatska, \\ $\mathrm{PhD}$ of Economics, associate Professor \\ Kyiv National University of Technologies and Design, \\ 2, Nemyrovycha-Danchenka Street, Kyiv, 01011, Ukraine, \\ ORCID: 0000-0003-1600-1481 \\ ResearcherID: D-4215-2019
}

\title{
CO-BRANDING OF BUSINESS STRUCTURES IN TOURISM
}

The article determines that ensuring the further development of travel agency requires their integration and creation of new integration forms in the form of business structures. It is proved that the business structure, as a way of consolidating the business of several travel agencies, requires the formation of its own brand. Co-branding technology is used for this purpose. Examples of co-branding in different tourist destinations are summarized and presented.

Keywords: branding, co-branding, business structure, integration, partnership.

Relevance of the research topic. The tourism sector is the most globalized sector of the world economy as it is constantly expanding its activities to the countries of the world, opening up new opportunities for development. Globalizing business development conditions require close cooperation and consolidated activity and new ways of cooperation from travel agency. This is very difficult to achieve in the context of disparate activity, so in the field of tourism, for the effective operation of enterprises are forced to create complex business structures that include businesses from different fields of activity and different countries require affiliation. Ensuring long-term troublefree functioning and sustainable development of enterprises in the tourism sector places the need for their integration and creation of new integration forms in the form of business structures. Under the business structure we mean the voluntary statutory or temporary merger of several enterprises of different ownership and (if necessary) individual entities (freelancers) into a single integrated complex open system operating 
in a globalized environment, with the aim of developing and commercializing innovative products that increase the efficiency of activities and accelerate the integration of economic entities that form such a structure [5].

Establishment of business structures is especially relevant for enterprises in the tourism industry, where most travel agency provide the same tourist products and services that the demanding consumer in most can distinguish only at the price of the offer. The experience of the world tourist market testifies to the successful functioning of tourism enterprises-giants (corporations), transnational in their form and monopoly in essence, created on the terms of unit participation or by absorption (merger) of large and small firms-operators and networks of travel agencies.

Traveling giants become owners of transport enterprises, accommodation and catering companies, chain stores, banks, insurance or security companies, etc., thus forming a corporate structure in vertical and horizontal forms of integration. The international nature of the business, the multi-sectoral nature of the tourism sector, the identification and exploitation of new markets for tourism services provide a wide field for innovative change and the synergistic effect of their introduction. For accurate identification of tourism products, travel agencies develop joint trademarks using cobranding technology.

Formulation of the problem. Creating one's own brand name is a key aspect in the modern development of the tourism industry and the competitive advantage of travel agencies, which clearly identifies them in the tourism market. However, using your own brand requires considerable time to develop and bring it to the mind of the consumer, investing financial resources in positioning and distributing the brand, which is difficult to do for travel agencies.

Analysis of recent research and publications. Co-branding of tourist destinations is increasingly attracting attention, with researchers typically focusing on the regional level or on consumer demand [10]. The issues of the use of co-branding in the tourism industry are devoted to the work of such well-known foreign researchers as S. Bernazani, T. Venetis, F. Kotler, V. Pferch, M. Robertson, as well as domestic researchers: O. Kovalchuk. O. Marchenko and other. Their work focuses on specific aspects of co-branding technology.

Setting objectives. The purpose of the study is to substantiate the necessity and peculiarities of the use of co-branding by business structures of the tourism industry, as one of the effective tools for their formation and development.

Presenting main material. Business structure, as a way of consolidating the business of several enterprises, can be created as a result of their merger, merger and acquisition, partnership. Mergers and acquisitions (in Ukraine accession) is one way of integrating enterprises that are in difficult economic conditions or termination of their activities, a way of implementing one of the participants' corporate strategy. Takeovers (or acquisitions) are the cessation of the existence of only one or more enterprises that 
join a «non-reorganized» core. As a result of the merger, both enterprises are reorganized and a new business structure is created. A partnership is a voluntary association of several companies for the joint implementation of a project, in which both enterprises do not cease to exist and do not change ownership.

For the formation of a business structure, one of the important points is its proper positioning on the market, remembering in the mind of the consumer, encouraging the consumer to buy the products of this particular business structure, which can be achieved through the formation of a brand. For this purpose, tourism technology uses branding as «a set of large-scale range of areas of work on content marketing tools, which in turn gives the opportunity to create the image of a tourism brand» [3, 134-138].

However, for a new business structure, «the process of branding is quite long, because it takes time for the objective characteristics of the product to be transformed into a brand of the company» [6] and requires significant financial costs. If both enterprises already had strong established brands before the integration, then it should be decided whether to create a new brand or better keep the already known consumer brands. In this case, a very effective modern form of strategic collaboration between existing well-known brands that «combine to create a joint product or service with a higher added value» [4] or create an business structure is co-branding. Co-branding is the joint placement of trademarks, logos and branding of business partners that realize the benefits of property partnerships [2].

The main purpose of co-branding a business structure in tourism is to form and further develop in the tourist positive associations associated with its brand or each of the brands of travel agency that have integrated into the entrepreneurial structure.

To achieve this, co-branding technology must take into account six classic features of the concept of «brand», formed by F. Kotler [4, p. 72-79]:

1. Attributes. The co-brand should appeal to the tourist for positive associations regarding the special features of the tourist structure of the business structure.

2. Advantages and benefits. The co-brand will be effective when the tourist gets new benefits and benefits from using it.

3. Values. The co-brand aims to reflect the consolidated value system of both enterprises that have combined to create it into an business structure.

4. Culture. The co-brand symbolizes the corporate culture of the business structure.

5. Individuality. The co-brand should emphasize the individuality and uniqueness of the tourist service of the business structure.

6. The consumer. The co-brand will be popular when a tourist receives positive emotions from using it.

Effective implementation of co-branding, its effectiveness depends on compliance with the mandatory conditions for promotion of co-brand of business structure in the tourism market, namely: 
1. Both tourism brands should have the same target audience. To do this, partner companies combine their existing customer bases to create a new tourism product.

2. Within the framework of a joint co-branding project, travel agency «combine their resources and creativity» in such a way that they do not create strategic contradictions [8], create a loyal audience, increase sales of tourism products, reduce costs for the development of sales networks.

3. If co-branding benefits only one of the participating companies, such cooperation is short-lived and productive.

Co-branding in tourism is carried out in different directions:

1. In the process of tourist travel. A good example of using co-branding is the TUI Group of companies formed in 2014 as a result of the merger of two of Europe's largest travel companies: German TUI AG and British TUI Travel PLC. The TUI Group serves over 20 million clients annually, offering holidays in 180 countries. TUI Group includes tour operators, more than 300 hotels in more than 30 countries, 6 airlines, 14 cruise ships and more. In Europe alone, TUI has more than 3,000 sales offices. TUI Group has the largest charter fleet in Europe - more than 130 aircraft. The group includes well-known hotels RIU, Club Magic Life, Suntopia, Iberotel, Robinson Club, Sol Y Mar Club, Coral Sea, Jaz Resort and many more.

2. To speed up tourist transactions. The world-renowned Apple and MasterCard have teamed up to create an Apple Pay app that lets travelers make any payment without a real credit card. The Apple Pay program allows tourists to store their credit card information on their mobile phone, so they can use it without having a physical card with them, which greatly accelerated the process of obtaining money, sales and other transactions of the tourist during the journey [1].

3. In the process of choosing a tourist route. A striking example is the merger of Ukrainian tour operator GTO Travel and Kazakhstan's Kompas, which have announced a joint venture with Kompas.

Companis Airbnb, a room sharing service and Flipboard, a newsgroup that gathers news and relevant content that users share on social media and allows you to view content similar to a social media feed, has created a collaborative product called «Trips» [9]. It allows Airbnb travelers to connect with shared interests and actually book this experience while traveling.

4. In the hospitality industry. Co-branding two related but distinct hotel brands within the same building led to the formation of combo hotels. Combo hotels, like a tourist business structure, all have different class rooms in the same building with more or less wide range of services for different categories of tourists, share amenities or elements of the hotel such as parking or lobby, gym or meeting facilities. For example, InterContinental Hotels Group (IHG) has created several joint venture hotels in the US and Canada using this technology. Canada has Holiday Inn Express and 
Candlewood Suites in Edmonton, as well as pipeline facilities including Staybridge Suites and Holiday Inn Express at Saskatoon University; a Staybridge Suites and Holiday Inn Express in Niagara on Lake Ontario; and two Candlewood and Holiday Inn Express hatches: in Grand Prairie, Alta and another in Vaughn, Ontario [11].

The use of co-branding in tourism is possible not only at the local level between individual travel agency, but also at the national and international levels. For example, in 2016, the Indonesian Ministry of Tourism signed a Memorandum of Understanding (MO) with 28 local brands and 100 companies for joint co-branding partnerships to increase the country's tourism attractiveness [12]. The result of such cooperation was the increase of Indonesia's tourism rating from 96 to 47 places in 2016 and the entry of the country to the top 20 tourist countries in the world.

Conclusions. Thus, the use of co-branding is a powerful effective tool that helps consolidate the business of several travel agency and can be carried out in different directions: when choosing a tourist route, to accelerate the tourist transactions, when choosing a holiday destination, in the hospitality industry. For travel agency, the co-brand allows increasing the distribution and awareness of both their brands and co-brand of the joint business structure in the tourism market, reflects the consolidated value system and corporate culture of both travel agency, emphasizes the individuality and uniqueness of the tourist service of the business structure. Co-branding offers new advantages and benefits to tourists, arouses positive associations and impressive emotions from its use.

\section{REFERENSES}

1. Deviat prykladiv uspishnykh ko-brendynhovykh prohram. NGM. Retrieved from: https://ngmsys.com/blog/9-best-co-branding-programs [in Russian].

2. Ko-brendynh. Discovered. Retrieved from: https://discovered.com.ua/ marketing/kobrending/ [in Ukrainian].

3. Kovalchuk, O. A. (2019) Vykorystannia brendynhu pidpryiemstva turystychnoi haluzi. Molodyi vchenyi. 11 (75). 134-138 [in Ukrainian].

4. Marchenko, O. A. (2019) Metodolohichni zasady ta stratehii formuvannia brendiv turystychnykh produktiv i posluh ta zdiisnennia brendynhu turystychnykh orhanizatsii. Retrieved from: https://www.pdaa.edu.ua/sites/default/files/nppdaa/ 10/10.pdf [in Ukrainian].

5. Shatska, Z. Ya. (2018) Sutnist definitsii poniattia «pidpryiemnytska struktura» ta pidkhody do yii traktuvannia. Visnyk KNUTD. Seriia «Ekonomichni nauky». (129). 111-124 [in Ukrainian].

6. Shymanska, I. O., Savetin V. H. \& Marchuk Yu. A. (2013) Brendynh, yak napriamok marketynhovoi diialnosti pidpryiemstva. Efektyvna ekonomika. 2. Retrieved from: http://www.economy.nayka.com.ua/?op=1\&z=1846 [in Ukrainian]. 
7. Trendsetter barometer. Business outlook. PwC's Barometer Surveys. Retrieved from: http://www.barometersurveys.com/ store/docs/Trendsetter\%20Ba-rometer\% 202Q\%20 2014\%20-\%20FINAL.pdf [in Ukrainian].

8. Robertson, M. (2019) How co-branding works: 7 great examples. Retrieved from: https://99designs.com/blog/marketing-advertising/co-branding/ [in Ukrainian].

9. Bernazzani, S. (2019) 18 Examples of Successful Co-Branding Partnerships (And Why They're So Great). Retrieved from: https://blog.hubspot.com/marketing/ best-cobranding-partnerships [in Ukrainian].

10. Network position and tourism firms' co-branding practice. Journal of Business Research. 2015. 68, 8. Retrieved from: https://www.sciencedirect.com/ science/article/abs/pii/S0148296315001393 [in Ukrainian].

11. Venetis, T. (2018) How co-branding hotels can offer broader market. Hotelier. Retrieved from: https://www.hoteliermagazine.com/how-co-branding-hotelscan-offer-broader-market-reach/ [in Ukrainian].

12. Tourism Ministry partners with 28 local brands for co-branding deal. Pesona Indonesia. 2017. 11. Retrieved from: https://www.thejakartapost.com/travel/ 2017/08/11/tourism-ministry-partners-with-28-local-brands-for-co-branding-deal.html [in Ukrainian].

13. Melnyk A. O., Chaplich I.A. (2009) Perspektyvy rozvytku vitchyznianoho turyzmu $\mathrm{v}$ umovakh yevroantlantychnoi intehratsii. Visnyk KhNU. Vol. 1. [in Ukrainian]. 